\title{
https://doi.org/10.24297/jssr.v14i0.8455
}

\section{Gender Audit for Gender Mainstreaming of Coastal and Marine Fishing Community of India}

\author{
Devaraj Asir Ramesh*, M.V. Bindu and N. Karthi
}

Scientists, National Centre for Sustainable Coastal Management, Ministry of Environment, Forest and Climate Anna University Campus, Chennai, Pin-600025 India.

asirramesh@gmail.com

\begin{abstract}
Fisherwomen constitute $47 \%$ of the total adult coastal and marine fishing populations in India. They share major contributions in the fishing of their families either directly or indirectly, especially in postharvest and land-based activities, including marketing. The activities performed by fisherwomen in fishing are diverse and differs to those of men but significant for the livelihood of their families. Fisherwomen activities amount high in the share of economic contribution to coastal fishing in India. The work performance of fisherwomen in fishing-related activities are un-recognized or underrecognized. Gender biased discrimination, such as access to resources, control over family, consumption pattern, and freedom for domestic expenditure, are prevalent in their family and community. Gender inequality slows down the economic development and deepens poverty in the fishing community. Inadequate recognition of fisherwomen's contribution to fisheries shall hamper the sustainable development process.
\end{abstract}

Gender equality is a basic of human rights, and its achievement shall bring many long term positive changes in human development and socio-economic progress. A gender audit assesses the extent to which gender equality is effectively institutionalized in the policies, programs, schemes, and in the corresponding budgets. To measure the gender gap in coastal fisheries in India, Gender Inequality Index (GII) has been applied. Accordingly, GII in fisheries is 0.618 , which is comparatively higher than that of the National average (0.563). This paper discusses the methods of analyzing gender gaps in the fisheries sector and requisite gender mainstream activities for fisherwomen empowerment.

Keywords: Fisherwomen, Gender Inequality, Gender Mainstreaming

\section{Introduction}

Worldwide, about 180 million women are working on fisheries and aquaculture related activities (Bliege Bird, 2007). FAO estimates that, overall, fishing and aquaculture assure the livelihoods of 10 $12 \%$ of the world's population (FAO, 2014). In the fishing activity, there is a strong division of labour in the coastal fishing families. Fisherwomen have been involved in gleaning, near-shore fishing, net mending, fishing, fish drying, processing, curing, peeling, packaging, and marketing etc, and shares $50 \%$ of the total labor force. In addition, the fishermen and fisherwomen are performing a complementary role throughout the capture fisheries value chain (Weeratunge and Snyder, 2010; Harrison, 2001). The work performance of fisherwomen in fishing-related activities is un-recognized or under recognised, which is evident through the invisibility of women's roles in many official fisheries statistics (Williams et al., 2002). Gender issues in fishing sector have been neglected for several reasons, including the following; (i) a belief of fishing and fisheries are the domain of men (ii) the concept of fisheries are limited to direct fishing activities (iii) the gender stereotype that of women as being physically weak and unsuited for the physical activities in fishing (iv) gender stereotype of fisherwomen are not technically minded (v) poor representation of fisherwomen in political, socio-economical employment in departments and academia (Nguyen Dang Hao, 2012). 
Inadequate recognition of fisherwomen's contribution in fisheries shall hamper the sustainable development process, resulting to increased poverty and food insecurity (FAO, 2016). Gender is the socially and culturally constructed identities of men and women. Gender refers to the roles, responsibilities, access, and opportunities of men and women, boys and girls, in a society. Gender equity refers to the process of fair and just treatment of women and men with equal opportunities and responsibilities to reach gender equality (World Bank,2012). Gender equality is a basic human right, and its achievement shall bring many long term positive changes in human development and socioeconomic progress (Diamond et al. 2003). Gender equality shall support the increase of sustainable production and economic growth in the fishing community (Elizabeth Ursic, 2014). Goal 5 of Millennium Sustainable Development focuses to "Achieve gender equality and empower all women and girls" (Brendan Fisher and Robin Naidoo, 2016). However, gender does not figure in the Code of Conduct for Responsible Fisheries (CCRF), but it came into the Ecosystem Approach to Fisheries (EAF) as an afterthought to ensure that human, and a fortiori gender, dimensions of fisheries were adequately covered in the implementation of the EAF (BOBLME, 2012). National plans, policies, institutions, and budgets of Governments have been translated into their commitments in gender equality. Yet, gender inequalities remain deeply entrenched in every society. They are too often denied access to basic education and health care. Women in all parts of the world suffer violence and discrimination. They are under-represented in political and economic decision-making processes. Gender-blind policies have resulted, massive losses in terms of production and income, as well as to household food security and nutrition, particularly for the poor (Maruf Hossan Chowdhury et al., 2015).

A gender audit assesses the extent to which gender equality is effectively institutionalized in the policies, programs, organisational structures, and proceedings (including decision-making processes) and the corresponding budgets. It evaluates whether the practice and systems for gender mainstreaming are effective and reinforce each other. Gender Inequality Index (GII) is a tool for gender audit to judge the losses of potential National achievement because of gender inequality in reproductive health, empowerment, and labour market participation (Nguyen Dang Hao, 2012). To understand the role and status of gender in the coastal fishing community in India and to enhance fisherwomen equality, a study was conducted to estimate the gender gap and to access productive resources, services, health, education, participation in governance, and markets. The study also finds the substantial gains that could be achieved by closing these gender gaps in the fishing community.

\section{About fisherwomen in India}

Coastal fishermen community is an essential stakeholder in coastal zones of India. The coastal fishermen population of India is distributed in 72 coastal districts. The active fishermen population in 3288 , coastal fishing villages was 5400000 (FAO, 2016). Fisherwomen constitute 47 percent of the total adult population in the fishing villages of India. Male and female population distribution of fisher folks has been given in Fig.1. The male and female ratio is varying with states. Kerala and Tamil Nadu fair better with their sex ratio scoring at 966 and 939 respectively (2010 marine census) but, Goa rank inferior in sex ratio among the states with only 625 females for 1000 males, which are lowest malefemale ratio among the States.

Fisherwomen activities amount high in the share of economic contribution to coastal fishing in India. It has been estimated that the percentage of women as a work force for total capture fisheries in India is $72 \%$ (World Bank, 2010). There is some gender-biased discrimination within the household that includes access to resources, control over family, consumption pattern, and freedom for domestic expenditure. Fisherwomen are migrated to nearby places to gain employment in fishing-related industries. But, their level of migration is primarily hampered by the social system in the fishing community. The working environment of fisherwomen is awful, whether it is market or peeling shed. The working environment of fisherwomen is the cause of many health hazards. Like complaints of 
arthritics, skin disorders, and back pain are common among the fisherwomen working in the processing plants (Sheela Immanuel et al., 2008).

Fisherwomen have a very low status in the social hierarchy, which leaves them worse off than their compatriot (Karuna Anbarasan, 1985). In general, women are non-entities when they come to community affairs. They are not eligible for election as village leaders, or as members of the village council, and they are not allowed to take part in village meetings (Natarajan and Vijay, 2014). Fisherwomen are victims of both backwardness and gender discrimination, and they are not bothering about the political arena (Pataik et al., 2011). Fisherwomen are unrepresented in leading positions, whether in elected offices, civil services, and private sector or academia. Now fisherwomen are elected as panchayat president, counselor, ward member, bank staff as well as they entered in academic line as teachers, engineers, and doctors, etc. Though, $73^{\text {rd }}$ and $74^{\text {th }}$ constitutional amendments are guiding reservations for women in Panchayat Raj Institutions. Fisherwomen participation in local governance is very rare. If fisherwomen have represented in the local management, their husband as a proxy shall play their role. Gender inequality slows down the economic development and deepens poverty in the fishing community. It is very imminent to recognize the gender equality for sustainable development and reduction of poverty (Fedon, 2004) in coastal fisheries of India.

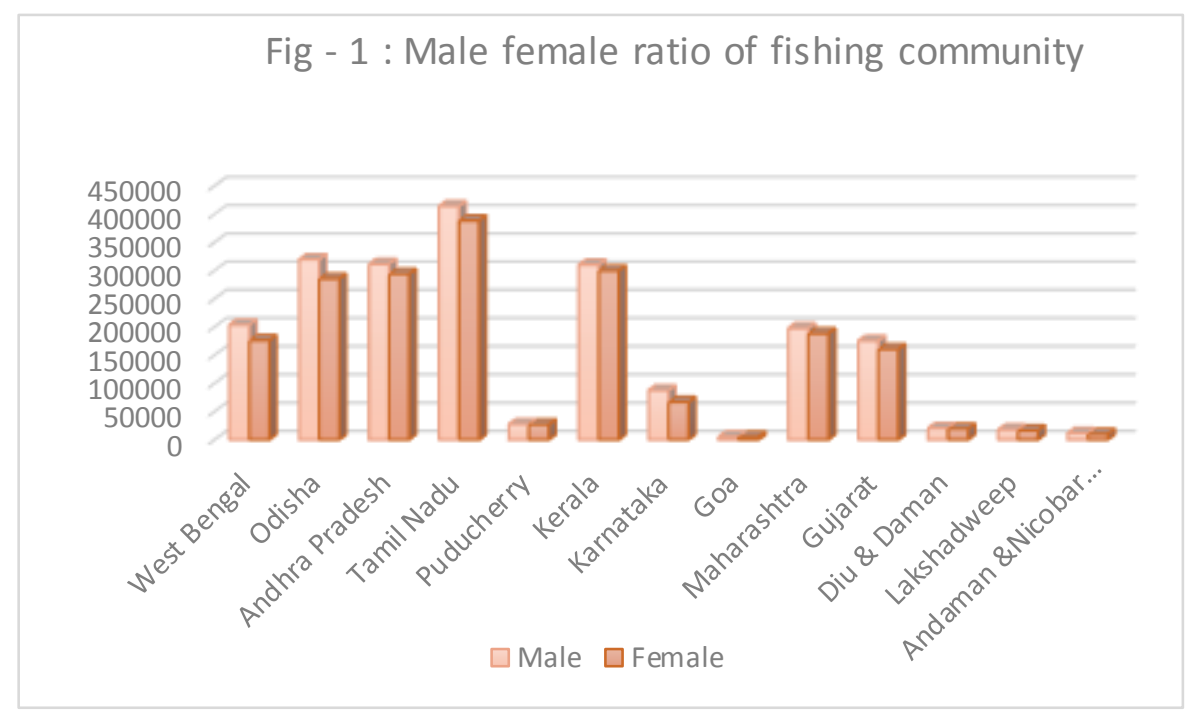

\section{Methods - Gender audit of fisherwomen}

Equality in terms of gender refers to differences between individuals in a society, particularly to differences in the positions of power that women and men hold in society (Maruf Hossan Chowdhury et al., 2015). Gender inequality can be assessed by the Gender Inequality Index (GII). GII aims to measure all dimensions of gender inequalities, avoiding the pitfalls of aggregation. It is a way of addressing the shortcomings of gender-specific measures through a new aggregate strategy using Multiple Correspondence Analysis (MCA) (Gaielle Ferrant, 2010). GII has been used to measure the gender inequality status of various nations of the world. In a list of 155 countries, India places at $130^{\text {th }}$ position, and its GII value is 0.563 whereas, the top ten countries have values below 0.05 . (HDR, 2014).

Gender inequalities are measured from three dimensions of the woman in development, i.e., reproductive health, empowerment, and participation in the workforce (Fig.2). These dimensions consist of 5 indicators they are; (i) Maternal Mortality Ratio (MMR) (ii) Adolescent Birth Rate ABR) (iii) Secondary Education (SE) (iv) share of seats in parliament (PR) (v) Labour Force Participation Rate (LFPR) (UNDP, 2014). 
The SI. No. (i) \& (ii) are measuring health dimension, SI. No. (iii \& iv) are comparing the male to estimate women empowerment dimension and SI. No (v) estimates the share in the workforce. To evaluate GII of fisherwomen in India, data for the indicators were collected from the Census of India 2011, Marine Fisheries

Fig - 2: Methods of measurement of women development

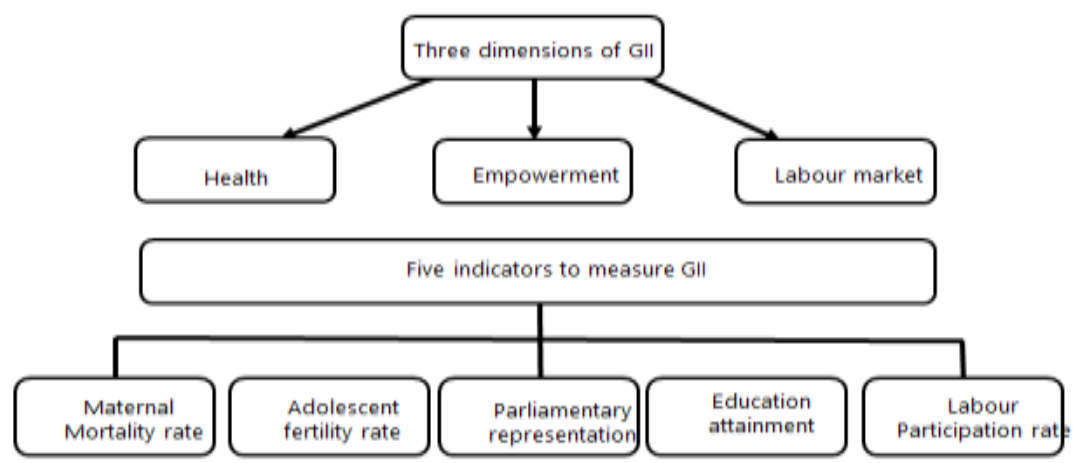

Census 2010, and State level fisheries census data. In addition, primary data of fisherwomen were collected using a multi-stage random sampling method (Table.1). In the multi-stage random sampling method, fisherwomen general profile (fifty samples from each fifty-three fishing villages) in five coastal states each viz., Odisha, Andhra Pradesh, Tamil Nadu, Kerala, and Gujarat were studied.

\begin{tabular}{|l|l|l|l|l|l|}
\hline \multicolumn{5}{|c|}{ Table - 1: Primary data - sample size of fisherwomen } \\
\hline Particulars & Gujarat & Kerala & $\begin{array}{l}\text { Andhra } \\
\text { Pradesh }\end{array}$ & Odisha & Tamil Nadu \\
\hline $\begin{array}{l}\text { No. of Coastal } \\
\text { District }\end{array}$ & 16 & 9 & 9 & 6 & 13 \\
\hline $\begin{array}{l}\text { No. of Marine } \\
\text { Fishing Village }\end{array}$ & 247 & 222 & 555 & 313 & 573 \\
\hline $\begin{array}{l}\text { Overall } \\
\text { Population of } \\
\text { Fisherfolk }\end{array}$ & 336131 & 610165 & 605423 & 605514 & 302912 \\
\hline $\begin{array}{l}\text { Number of } \\
\text { Sampled Village }\end{array}$ & 20 & 20 & 50 & 29 & 24 \\
\hline $\begin{array}{l}\text { No. of fishermen } \\
\text { families }\end{array}$ & 62231 & 113937 & 163427 & 114233 & 192697 \\
\hline $\begin{array}{l}\text { Number of } \\
\text { Respondents }\end{array}$ & 1197 & 1000 & 2002 & 1500 & 1136 \\
\hline
\end{tabular}

Primary data was on socio-economic indicators of the fisher women, including occupation, income, properties, education, health decision making, and participatory role of women in community activities were collected to provide input for GII calculations. Using the above primary and secondary information on GII indicators, the following formulas were applied to estimate the GII of fisherwomen;Geometric means across dimensions in each gender group were calculated using two methods. To estimate female geometric mean (GF) 


$$
G F=3 \sqrt{ }(I M M R \cdot 1 / A B R)^{1 / 2} \cdot(P R F . S E F)^{1 / 2} \cdot \text { LFPRF }
$$

To estimate male geometric mean (GM)

$$
G M=3 \sqrt{ } 1 \cdot\left(P R M \cdot S E_{M}\right)^{1 / 2} \cdot \operatorname{LFPRM}_{M}
$$

The harmonic mean was formulated to create the equally distributed gender index using the following equation:

$\left.\operatorname{Harm}\left(G_{F}, G_{M}\right)=\left(G_{F}\right)^{-1}+\left(G_{M}\right) / 2^{-1} /\right]^{-1}$

To calculate the geometric mean of each indicator:

$$
G_{F . M}=\sqrt[3]{\text { Health.Empowerment } . L F P R}
$$

Finally, to calculate GII, the following formula was used.

$$
G \| l=1-\operatorname{Harm}\left(G_{F}, G_{M}\right) / G_{F, M}
$$

The gender status of fisherwomen using the GII was analysed, and the values were compared with the National average for discussion on policy guidance on gender mainstreaming.

\section{Results and Discussion}

\section{Reproductive health}

Reproductive health has been placed as the first indicators to measure GII since reproductive health accounts for the largest loss due to gender inequality. Reproductive health implies the ability of people to have a responsible, satisfying, and safer sex life to reproduce and the freedom to decide if, when, and how often to do so (WHO, 2011). In general, two indicators have been used to capture the reproductive health dimension of a country they are; (i) maternal mortality rate and (ii) adolescent birth rate (Amie Gaye et al., 2010). Sexual and reproductive health has been recognized in international human rights law, particularly in the areas of adolescents' rights, maternal health, and family planning. It is the right of women to access information and services relating to partnerships, marriage, sexual relations, and the bearing of children to make decisions towards equality and well-being (UNFPA, 2010). It is widely accepted that women's health during pregnancy and childbearing is a clear sign of women's status in society (UNDP, 2014). Malnutrition among women in general and during the pre and post-natal period, lack of awareness on nutritional and balanced diets increase their vulnerability to health risks. Research findings have informed that the fishing community in India has many occupational health problems, malnutrition, under-nutrition, poor hygiene, poor sanitation, and lack of adequate health facilities (ICOR, 2011).

Maternal Mortality Ratio (MMR) Maternal mortality rate (MM Rate) is defined as the number of maternal deaths in a population divided by the number of women aged 15-49 years (or woman years lived at ages 15-49 years) (WHO, 2012). In India, maternal mortality is 200 (ratio) deaths per 1, 00,000 live births (HDR, 2014). Gender inequality weakens maternal health and harms children through many direct and indirect pathways. Allied biological disadvantage and psychosocial adversities challenge the survival of children of both genders. Various empirical studies have confirmed the association between maternal health, violence against women, and child mortality rates in rural areas (Ethel Mary Brinda et al., 2015). 
Sample Registration System (SRS), a continual demographic survey conducted by the Office of the Registrar General of India, is being used the pooled data of three years to estimate the MMR and its details fig.3. Based on the pooled data estimation, it has been identified that many maternal deaths in India are due to poor nutrition, poverty, and socioeconomic marginalisation (William Joe et al., 2015).

Fig-3 : Maternal mortality rate in fishing community \& National avg.

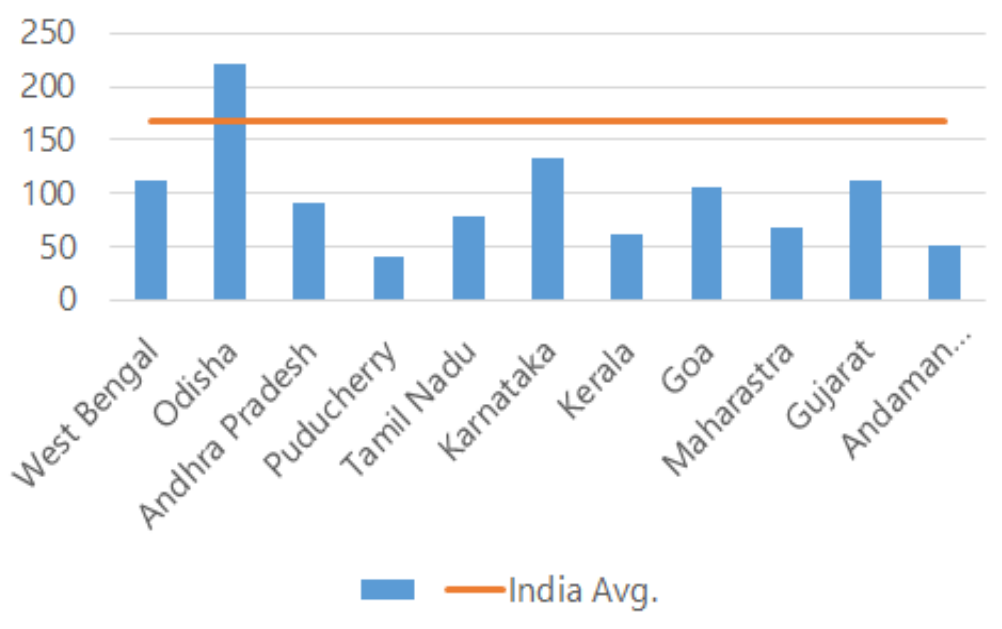

An analysis of 124 maternal deaths (in 2012-13) across ten major states of India reveals that about $28 \%$ of deaths are due to haemorrhage (Subha Sri and Khanna, 2014). The MMR is varying between various States and regions depending upon the purchasing power of individuals, health care facilities, and investment in public health care services. MMR of 465 was enumerated for the coastal fisherwomen out of 2365 births in five coastal States. This value is higher than the national average of 200 MMR. Among the coastal States and UTs, Odisha state MMR is (225) $12.5 \%$ higher than the national average. This shows little access to reproductive health services by fisherwomen comparatively. Distance from hospitals (or) health centers, lack of health insurance, unaffordable fees, poverty, and lack of commitment of the family and community may be the factors. In addition, fisherwomen income shall be used for better nutrition, food production capacity, access to affordable reproductive health, transport, water, and sanitation, all of which have an impact on maternal health. Due to poor income or insufficient income dependency on reproductive health decisions in their family may lead to maternal death. Countries with a high GII also had a high MMR as compared with countries with lower GIIs (Frank Chirowa et al., 2013).

\section{Adolescent Birth Rate}

The number of births to women ages 15-19 per 1,000 women in that age group per year is called Adolescent Birth Rate (WHO, 2010). This indicator highlights that reproduction is not only risky, it often begins too early, and scope for future opportunities of the adolescent are limited (Amie Gaye et al., 2010). Globally, early childbearing often results in women in higher total fertility, lost development opportunities, limited life options, and poorer health. Children of adolescent mothers are with low birth weight, malnutrition, and anemia. Pregnancies among girls less than 18 years of age have irreparable consequences. It violates the rights of girls, with life-threatening consequences in terms of sexual and reproductive health, and poses high development costs for communities, particularly in perpetuating the cycle of poverty. Huge age gap between spouses also means huge power differentials more likely to experience violence within marriage or a partnership (Edilberto Loaiza and 
Mengjia Liang., 2013). Every year, nearly 16 million adolescent girls give birth, the majority of whom are married. The national ABR of India is 32.8. ABR of coastal States has been given in Fig.4.To estimate

the $A B R$ in fisherwomen, marriages of 6757 coastal fisherwomen living in 53 coastal villages of 5 coastal states were appraised and found that 256 fisherwomen (3.8\%) were married in adolescent age, out of which $90 \%$ are given birth in their adolescent age. These results showed that the ABR of fisherwomen is 37.9, which is higher than the national average. WHO (2012) suggested that education itself is a major protective factor for early pregnancy. More years of schooling leads to fewer early pregnancies, and it is evident that the birth rates among women with low education are higher than

Fig. - $4: A B R$ in fishing community and National avg.

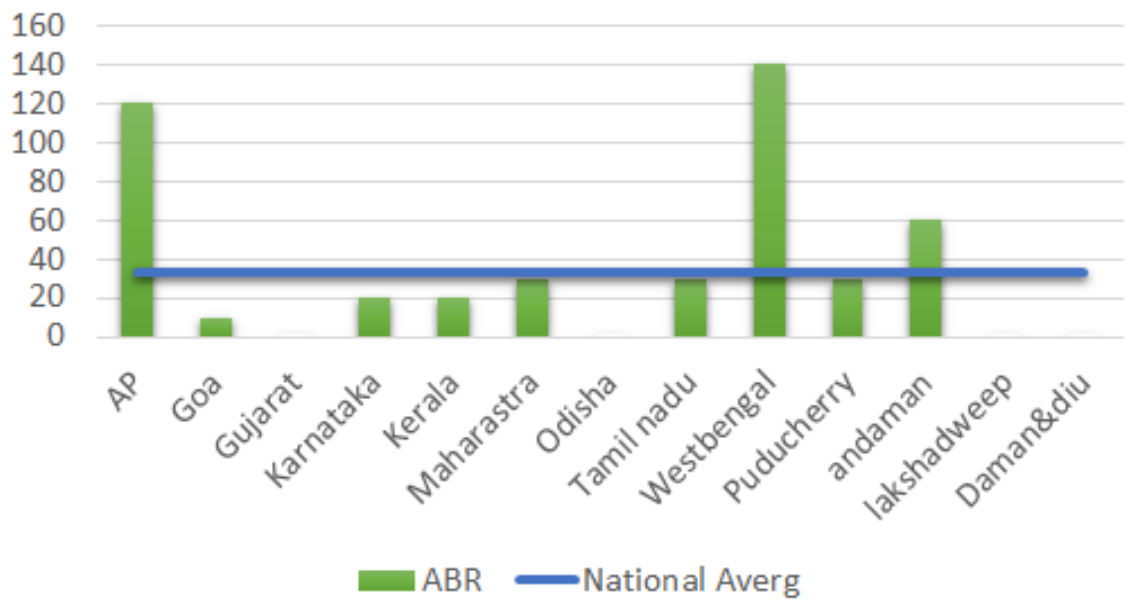

for those with secondary or tertiary education (WHO, 2012). Empowering fisherwomen by education and decision making is necessary for their own, for their family, and for the community.

\section{Fisherwomen empowerment}

Empowering women is not only matters of justice; it is also a smart strategy for strengthening fisheries development and food and nutrition security (FAO, 2013; Janet G. Stotsky, 2016). Women's participation in electoral competitions is an important indicator to measure the effective functioning of democracy (Thomas and Wilcox, 2005). Empowerment of women is being calculated by working out the ratio between the total number of Parliament seats, and the number of women representatives, and the proportion of adult females and males with secondary education is the indicators of empowerment dimensions of GII. Though the number of Parliament seats for women is a large unit to interpret the fishing women representation, share of leadership in the next levels (Legislative Assemblies) were analyzed in this study. Accordingly, the share of assembly seats by fisherwomen in coastal States was studied to measure the status of empowerment.

\section{Electoral representations of fisherwomen (Legislative Assembly Representation - LAR)}

Participation in the legislative process of women shows equality and freedom. In addition, it cuts across genders in sharing political power and providing liberty and space to women within the democratic framework of electoral politics (Praveen Rai, 2017). The equal rights of women in electoral politics have been given in Preamble of the Constitution of India where, it has been promised to secure 'justice, social, economic and political', as well as equality of status and opportunity' of all its citizens. 
Though the constitutional mandate provides equality of women in the public domain, including electoral politics, prejudice, and discrimination prevail against women (Akerker, 1995).

Fisherwomen are traditionally being disadvantaged in the electoral political arena at all levels in representation for decision making (Amie Gaye et al., 2010). In GII, women's political representations have been measured by the share of female seats in National Parliaments (Janet G. Stotsky, 2016) since the study focus on the fishing community who has a $0.5 \%$ share of the total population and the share of fisherwomen representation in the legislative assembly was enumerated. Since empirical data for women's electoral participation in India available for State and National elections (Praveen Rai, 2017), the open-source information was collected for analysis. In the measurement of women representation in Parliament of India has been observed that the $15^{\text {th }}$ Lok Sabha elections had achieved up to the halfway mark of the world average of $22 \%$ representation of women in Parliaments (Praveen Rai, 2017). In total, 53 women, parliamentarians ( $15^{\text {th }}$ Lok Sabha) are sharing $10.9 \%$ of total seats. Analysis of open-source information about the Parliamentarian details of India reveals that there are no fisherwomen Parliamentarians.

Fisherwomen participation in Legislative Assemblies of various State Governments and Union Territories reveals that no fisherwomen exist as a Legislative Member though 45 number of women legislators have been elected. In the GII measurement method, female parliamentary representation of countries reporting $0 \%$ is coded as $0.1 \%$ because it seems reasonable to assume that there is some very minimal level of the political influence of women in all countries (Amie Gaye et al., 2010). Using the above GII measurement, the fisherwomen GII value is $0.1 \%$. Accordingly, the electoral representation of fisherwomen in the legislative assembly indicator for the GII is 0 . The $73^{\text {rd }}$ and $74^{\text {th }}$ amendments to the Indian Constitution in 1993 introduced a 33-50\% reservation for women in institutions of local governance and other Panchayat Raj Institutions (PRIs) (Ghosh and Lama Rewal, 2005;). It has been estimated that 59528 numbers of coastal PRIs exist in 13 coastal states and UTs. In the local government (Panchayat Raj), however, the number of fisherwomen presidents could not be identified due to poor database.

\section{Secondary education}

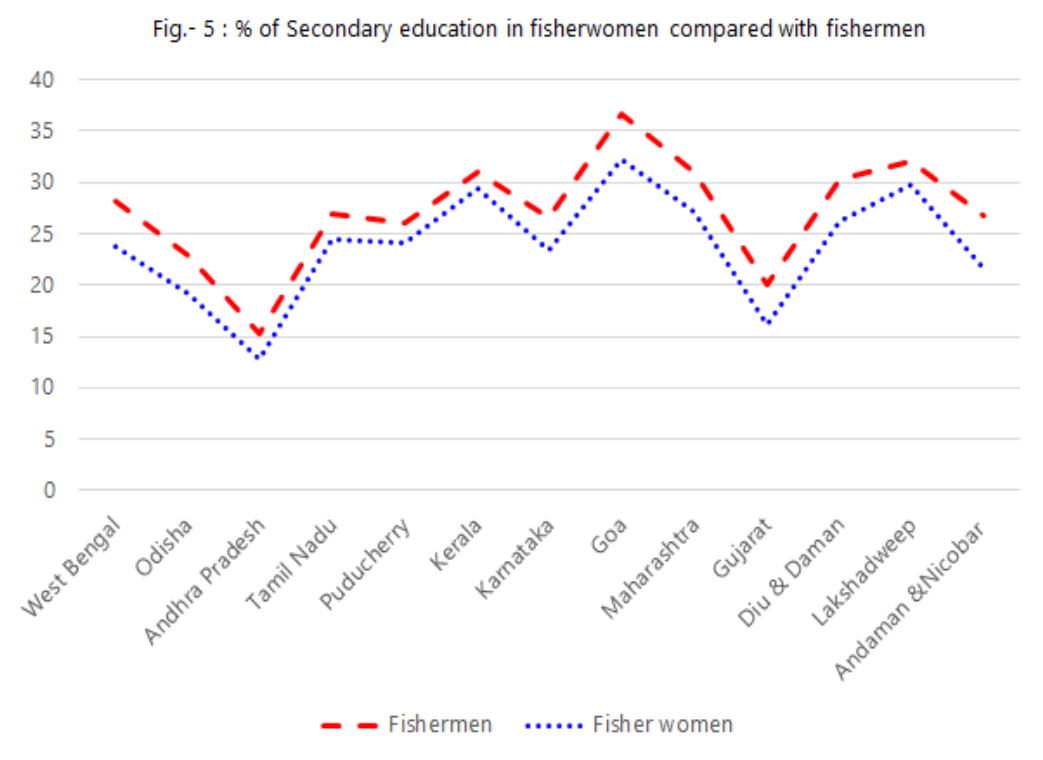

Education is one of the essential livelihood asset and capital for coastal fishing community development (Devaraj Asir Ramesh et al., 2017). The level of illiteracy has an impact on productivity at work. Illiterate women find it increasingly difficult adapting to new technology-based development. 
The literacy rate has been used as a primary indicator to measure the Human Development Index $(\mathrm{HDI})$, and secondary education is one of the important GII indicators to measure women empowerment (fig.5.).

Women in fishing communities are often illiterate and lack access to training and other opportunities to improve their marketable skills (Williams et al. 2002). Among the coastal fishermen population in India, literates share is $61.57 \%$ (crude literacy rate), which is very lower to the National average of 74 $\%$, which indicates that the difference of fishermen population in literacy is also the requirement of attention for the socio-economic development.

Along with the literacy rate, higher education of fishermen is also poor (2\%) while comparing the National average of 11\% (Devaraj Asir Ramesh et al., 2017). Active fisherwomen in the coastal areas of India are 2538000 , among which $23 \%$ of fisherwomen and $27 \%$ of fishermen are qualified in secondary education and above (CMFRI, 2010). This secondary education qualification is comparatively very poor in comparison to the National average of $26.6 \%$ and $50.4 \%$ of female and male population aged 25 and above, respectively. Low incomes, the nature of the fisheries, and the dependency of children in fishing activities to raise the family income and attitudes prevent the children from attending the inflexible formal school system (Devaraj Asir Ramesh et al., 2017).

\section{Labour Force Participation Rate (LFPR)}

Labour force participation rate is defined as the section of the working population in the age group of 16-64 in the economy currently employed or seeking employment. People who are still undergoing studies, housewives, and persons above the age of 64 are not reckoned in the labor force. Women's roles in fisheries in India are primarily in the post-harvest sector. Their quantum of outputs is limited by their low investment and risk-bearing abilities. Poor credit and access to resources are preventing fisherwomen to use modern technologies such as ice room and cleansing room for proper storage (Siason et al., 2002). Generally, technology development in the fishing sector hurts the fisher-women who are practicing traditional beach-based postharvest activity.

Technology and mechanization of fish production in India slowly displaced the traditional fisherwomen jobs in fisheries. For example, motorization and mechanization of fishing vessels led to a concentration of fish landings at fewer harbors and landing sites that resulted in the takeover of fish trade and marketing by merchants (Tietze, 2007). In addition, poor infrastructure and equipment lead to large post-harvest quality losses, resulting in lower incomes throughout the value chain. This affects both gender, but women are often more affected due to family responsibilities and poor access to transport facilities to reach distant markets (FAO, 2013). In general, industrial fisheries are practicing occupational segregation by employing women in low-skilled and low-paid jobs, while men have been placed predominately in skilled and managerial works. These managerial and skilled technical positions are under contractual services with job security and benefits. Women are generally less paid than men, even for the same work. In addition, the above jobs are characterized by the prevalence of seasonal, short-term, and casual jobs for both men and women. The works have been performed by contractual arrangements without any occupational protection or social benefits (FAO, 2013).

Women are completely excluded from fishing operations, and they come into picture only after landing of fish catch. A fisherwoman spends more than $90 \%$ of the time duration for fishing and allied activities in a year. Hence it is classified under full-time employment. The majority of them spend 225250 days (7.5-8 months) in dry fish production-related activities. In the lean period, they work as a laborer in, processing company, peeling factory, net weaving, or in the agriculture fields. Many active fisherwomen involved in fish seed collection on a part-time basis. About $20 \%$ of the coastal fisherwomen are working in fishing and allied activities such as marketing of fish, making/repairing net, curing/processing, peeling, and other fishing related laborers. Only about $0.66 \%$ of them are 
working in non-fisheries associated activities. The workforce shares in fishing-related activities have been varied between the coastal districts and States. In the fish marketing workforce, $81 \%$ of fisherwomen are engaged in Maharashtra, followed by Andra Pradesh (19.04\%) and Tamilnadu (18.05\%). The majority of the fisherwomen are engaged in making and repairing the fish net in the state of West Bengal (34.15\%), followed by Maharashtra (19.21\%) and Odisha (18.08\%) (CMFRI, 2010). Only $15 \%$ of the respondents (total 944) sampled in 5 coastal States; fisherwomen have owned small scale fishing-related equipment. Limitations in fisherwomen's ownership of fishing equipment's restrict them to engage in coastal fishing and allied activities (Ali, 1996). Using the disadvantage of restriction in ownership of resources and fishing equipment's, local / private money lenders are lending money for high interest rate in emergencies of fisherwomen in family activities, Self Help Group (SHGs) formal microcredit, bank, and cooperative society is the common saving facilities used by fisherwomen to enlarge the fishing related developmental activities. SHGs have been widely us ed for labor force participation since they are easily accessible and popular, and banks are falling as a distant second option (Rupnawar and Upadhye, 2015).

Balanced, equitable, and sustainable development of the fisheries sector must take all social groups into account. LFTR of fisherwomen confirmed that their contribution to the labour force in the fishing sector is unrecognized or under-recognized. LFTR of fisherwomen of India has been estimated as 23 $\%$. The above value is very near to the National average of women labor force participation percentage (ages older than 15) 28.8 (HDR, 2014). GII in LFTR for fisherwomen in India has been estimated as 0.593. Primary and secondary information on the workforce of fisherwomen is not documented in any books of policymakers and legislators (Maetala 2009).

\section{Fishers Gender Inequality Index}

Using the GII enumeration method, GII in fisheries is 0.618 . Table 2. explains the various indicators of GII of fisherwomen in India. The GII of fisheries is comparatively $4.2 \%$ higher than the national average. This empirical evidence confirms that the fisherwomen are disadvantageous in access to opportunities and resources, and there is a lack of measurement of their labor. The GII indicator also indicates that the gender inequalities prevail in areas such as education and training, access to independent credit, bargaining power in trade, role in decision making, and workplace environments. It is a question of human rights, which was guaranteed in legislation and policies. This continuous ignorance of fisherwomen rights shall hurdle sustainable fisheries development. Considering male advantages in terms of access to resources, education, and training since they are harvesting from the nature that often results in the weak representation of female fish (or other value chain) workers in membership and leadership roles (FAO, 2013).

The inequality gap shall be addressed explicitly by the implementation of gender mainstreaming activities and review of schemes to encourage the participation of fisherwomen in decision making, provisions to access capital equipment and technology, credit and loans, training, and education (Williams et al., 2002). National and states welfare scheme for fishers are not supporting fisherwomen except the saving cum relief scheme where compensation for the lean period of three months from the nine-month savings of fishers along with the Government contribution at the level of 1:2(fishermen $=1$ and Governments share $=2$ ) is being distributed to fishermen and fisherwomen. Gender inclusion in all fishing related activities shall bring substantial benefits, including the increase of productivity and income, reduced post-harvest losses, improved quality management, improved household food security and nutrition, and improved natural resources management through women's empowerment in the community (FAO, 2013). 
Table - 2: Fishers Gender In-equality Index

\begin{tabular}{|c|c|c|c|c|}
\hline $\begin{array}{l}\mathbf{S} \\
\mathbf{N} \\
\mathbf{O}\end{array}$ & Indicators & $\begin{array}{l}\text { National } \\
\text { Aver. } \\
\text { HDR(2014) } \\
\end{array}$ & $\begin{array}{l}\text { Fisherwo } \\
\text { men / } \\
\text { communi }\end{array}$ & Description \\
\hline 1 & $\begin{array}{l}\text { Maternal } \\
\text { mortality ratio } \\
\text { (deaths / } 100000\end{array}$ & 200 & 465 & $\begin{array}{lcr}\text { Total } & 50 & \text { fisher } \\
\text { women per } 53 \text { fishing }\end{array}$ \\
\hline 2 & $\begin{array}{l}\text { Adolescent birth } \\
\text { rate (births/1000 } \\
\text { women aged } 15-\end{array}$ & 32.79 & 37.9 & $\begin{array}{l}\text { Estimated from the } 6757 \\
\text { fisherwomen in } 53 \\
\text { villages of five coastal }\end{array}$ \\
\hline 3 & $\begin{array}{l}\text { Share of seats in } \\
\text { Parliament (\% } \\
\text { held bv women) }\end{array}$ & 10.886 & 0.1 & $\begin{array}{l}\text { The fisherwomen } \\
\text { representation in }\end{array}$ \\
\hline 4 & $\begin{array}{l}\text { Population with at } \\
\text { least some } \\
\text { secondary }\end{array}$ & 26.6 & 23.76 & $\begin{array}{l}\text { CMFRI,2010 Data } \\
\text { Source }\end{array}$ \\
\hline 5 & $\begin{array}{l}\text { Population with at } \\
\text { least some } \\
\text { secondary }\end{array}$ & 50.4 & 27.23 & $\begin{array}{l}\text { CMFRI,2010 } \\
\text { source }\end{array}$ \\
\hline 6 & $\begin{array}{l}\text { Labour force } \\
\text { participation } \\
\text { rate, female }(\%\end{array}$ & 28.8 & 28.3 & $\begin{array}{l}\text { CMFRI,2010 data } \\
\text { source }\end{array}$ \\
\hline 7 & $\begin{array}{l}\text { Labour force } \\
\text { participation } \\
\text { rate, male } \% \text { of }\end{array}$ & 80.9 & 72 & $\begin{array}{l}\text { Data source } \\
\text { CMFRI,2010 }\end{array}$ \\
\hline 8 & $\begin{array}{l}\text { Gender inequality } \\
\text { index }\end{array}$ & 0.563 & 0.618 & $\begin{array}{l}\text { Described in } \\
\text { methodology }\end{array}$ \\
\hline
\end{tabular}

\section{Gender mainstreaming in fisheries}

Gender mainstreaming is a process of change, a "transformation of unequal social and institutional structures into equal and just structures for both men and women". The International Labour Organization (ILO, 2002) described that mainstreaming is not about adding woman's component or gender equality component in an existing activity, it shall increase women's participation, bring experience, knowledge, and interests of women and men to bear on the development agenda (Cecile Brugere, 2014). Gender mainstreaming initiatives would modify the social and cultural pattern of conduct of men and women to achieve the elimination of prejudices and customary and practices which are based on the idea of the inferiority or the superiority of either of the sexes or stereotyped roles for men and women.

Gender mainstreaming requires that gender analysis be incorporated into all existing policies and decisions of fishing communities towards gender equality. Constitution and Government policies of India are emphasising gender equity however;, gender mainstreaming is trending at the slow progress. Gender mainstreaming is a key agenda for the Ministry of Women and Child Development (MWCD) of the Government of India. The Ministry has emphasized that gender budgeting is an important tool for gender mainstreaming. Its gender mainstreaming guideline has advised the States to issue notifications to adopt gender budgeting (D.O.NO. 1-25/2012-GB, dated 18th February, 2013). Accordingly, gender budgeting is a process to incorporate gender perspective at all levels and stages, 
including planning /policy/program formulation, assessment of needs of target groups, allocation of resources, implementation, impact assessment, and prioritisation of resources. In the fishing sector, local level fishing village plans are mandatory as per the Coastal Regulation Zone (CRZ) Notification under the Environment Protection Act 1986. In the fishing village plans, incorporation of gender mainstreaming tools shall be incorporated towards gender equity. As women have generally played minor roles in collective fishery organizations, there is a vital need to build women's leadership roles in all the relevant organizations to sensitize men to respectand support women leaders and to address gender inequities in the fisheries sector (FAO, 2013).

A growing body of evidence suggests that increasing a woman's control over assets has positive effects on important development and conservation outcomes for the household, including food security, child nutrition, and education as well as individual well-being (Quisumbing, 2003). Equal property rights of fishing women in properties such as crafts, gears, lands shall be emphasized in the fishing village planning. The traditional rights of fishing areas shall be transferred to female members also if male heirs to succeed. Women who are single or widowed may face more problems in fishing hence; specific local level laws are needed to ensure fishermen's widows have access to fish for subsistence fishing, food security and to generate economy (Danika Lynn Kleiber, 2014).

Self Help Groups (SHGs) of informal sectors of the fisheries and allied activities shall be emphasized in the fishing village plans to get benefits and for representation as stakeholders to participate in the decision making the process. Women SHGs of fishing villages shall be strengthened for promoting income generation activities. SHG based microfinance has contributed as a catalyst for the social change, and the empowerment of the poor is proved to be a boon for the rural women in some states of India (Meenu Maheshwari and Royal, 2014). SHGs shall be emphasised to enhance the investments in the fishery activities to facilitate the application and uses of various fisheries-related technologies and standards to match with the modern trends in fishing industries and consumer preferences. Joint Forest Management (JFM) scheme of India is very successful in resource sharing and $50 \%$ participation of women in forest resources management (Planning Commission, 2010). JFM principles shall be applied in coastal fishing resource management and management of common properties and fishing community resources, including CRZ areas.

The increase of jobs and a decent work environment are essential for inclusive growth that advances the economic and social development of fisherwomen. Fisherwomen shall be provided access to physical and financial capital to procure adequate infrastructure, equipment, technologies, and access to markets to ensure the implementation of their aspirations. To provide adequate facilities to fisherwomen, separate budget and allocation shall be made in the short and long term basis. Since the national budget mentions either women or men, the common assumption is that the money allocated benefit both genders to the same degree. However, this appearance of gender-neutrality is more accurately described as gender-blindness (Elson, 1997). Hence, gender budget shall be expressed in local-level plans to improve the status of women in general and the economic power of women in particular (Barbara Swirski, 2002). It is necessary to provide them with training and formal and informal education to improve the efficiency, profitability, and sustainability of their activities (FAO, 2016).

\section{Conclusions}

Socio-economic empowerment of fisherwomen shall meaningfully contribute to the well-being of themselves, their families, and their communities. Ultimately, this will help to create a responsible coastal fishing environment towards sustainable utilization of fisheries resources, contribution to human well-being, food security, and poverty alleviation. To create such a socio-economic environment for the coastal fishing women, appropriate institutional arrangements with guidelines for equal participation of fisherwomen in all fishing related activities are essential to reduce the gender 
gap in the fishing community. Existing constitutional and legal provisions, including CRZ 2011 and Panchayat Raj, are providing many direct and indirect directions to reduce the gender gap, which shall be immediately implemented by the States, UTs' and local Governments to empower fisherwomen. In the planning of fishing village, empowering fisherwomen in taking leadership, participation, and representation in all decisions is appropriate since they are responsible for all fishery-related activities in the shore (fishing village), including transporting, marketing, processing, housekeeping, etc. SHGs shall be strengthened by providing financial and legal support. Continuous technological inventions in the subsistence fishery shall enhance food security and improve their working environment of fisherwomen. Education and capacity building activities to fisherwomen shall empower them in financial, social, and political equity to achieve gender mainstreaming. To reduce the gender gap in fisheries, relevant policies, regulations, and schemes shall be rearranged to promote gender equity and equality of fisherwomen. Further, this study proved that the GII methods could be applied to estimate gender equality at the community, local levels, and for academic purposes.

\section{Acknowledgments}

The authors thank the fisherwomen of the coastal State of India for sparing their time to provide information about gender issues in their villages. The authors wish to thank the departments and organizations for sharing primary and secondary data about the fisherwomen. The authors express their gratitude to the Ministry of Environment Forests and Climate Change, New Delhi, and the World Bank, New Delhi, for their continuous support in capacity development activities of coastal management in India. Many experts have given valuable suggestions, comments, and critiques on this gender assessment study. Especially, guidance and encouragement of the Director, NCSCM, Dr. Purvaja Ramachandran, Division Chair, NCSCM, Dr.A. Senthil Vel, Advisor, MoEFCC, Shri. Tapas Paul \& Shri. Ramakrishna, the World Bank, New Delhi, and Shri. Rajagopalan, IAS, for facilitating this gender audit exercise. The authors wish to thank the colleagues at various departments of NCSCM, especially, Dr. Rajakumari and Dr. Sridhar, for sharing data and providing inputs for this gender mainstreaming study. The opinions expressed in this publication are those of the authors concerned and do not necessarily represent the views of the organizations that they are attached to.

\section{References}

1. Agarwal, B. (1996), "A Field of One's Own: Gender and Land Rights in South Asia", Cambridge University Press, Cambridge.

2. Akerkar Supriya. (1995), "Theory and Practice of Women's Movement in India: A Discourse Analysis", Economic and Political Weekly, Vol. 30 No.17, pp. 2-22.

3. Ali, S. M. (1996), "Marine Fisheries Economics and Development in India", Technology \& Engineering, 208, pp. 67-68.

4. Amie Gaye, Jeni Klugman, Milorad Kovacevic, Sarah Twigg, and Eduardo Zambrano. (2010), "Measuring Key Disparities in Human Development", The Gender Inequality Index. United Nations Development Programme Human Development Reports Research Paper, No. 46, pp. 1- 42.

5. Angela Lentisco and Enrique Alonso. (2012), "On Gender Mainstreaming Strategies and Tools in Fisheries Development Projects": RFLP Gender Strategy and Lessons from the Asia-Pacific Region. Asian Fisheries Science Special Issue, 25, pp. 105-117.

6. Aswani, S., and P, Weiant. (2003), "Shellfish monitoring and women's participatory management in Roviana, Solomon Islands". SPC Women in Fisheries Information Bulletin, 12: 3-11. 
7. Barbara Swirski. (2002). "What is Gender Audit?" ADVAI Center. Information on equality and social justice in Israel, pp1-17.Website: http://www.internationalbudget.org/wp content/uploads/What-is-a-Gender-Audit.pdf visited on 30/08/2017.

8. Bliege Bird, R.L. (2007), "Fishing and the Sexual Division of Labor among the Meriam". American Anthropologist, 109, pp. 442-451.

9. Boblme. (2012), "Mainstreaming Gender in the BOBLME Project', Socioec, 2 pp.1-79. BOBLME, $\mathrm{FAO} / \mathrm{GEF}$.

10. Brendan, Fisher, and Robin, Naidoo. (2016), "The Geography of Gender Inequality", PLOS ONE 11,3: e0145778.doi: 10.1371/journal.pone.0145778.

11. Cecile, Brugere. (2014), "Mainstreaming gender in trans boundary natural resources projects the experience of the Bay of Bengal Large Marine Ecosystem (BOBLME) project." Environmental Development, 11, pp. 84-97.

12. Chapman, M.D. (1987), "Women's fishing in Oceania", Human Ecology, 15, pp. 267-288.

13. CMFRI, (2010), "Marine Fisheries Census 2010 Part I India"'. Ministry of Agriculture, Krishi Bhavan, New Delhi, and CMFRI, Kochi.

14. Danika Lynn, Kleiber. (2014), "Gender and small-scale fisheries in the Central Philippines". A thesis submitted in partial fulfilment of the requirements for the degree of Doctor of Philosophy in the Faculty of Graduate and Postdoctoral studies. The University of British Columbia, pp.1-167.

15. Devadas. R.P and Nirmala, Murty. (1979), "Nutrient intake and deficiency diseases in fisherman community". C.M.F.R.I Bull. 30A. Cochin.

16. Devaraj Asir Ramesh, Priya Narayanan, Karthi, Priya Rajeev, Arumugam Senthil Vel, S.V. Reddy, and Ramesh Ramachandran. (2017), "Study about education and skill development of the coastal fishing community for sustainable livelihood". In Dr. Sujit Kumar Paul, Visva Bharati (ed.), "Sustainable development through education." New Delhi, APRAN Publication, pp. 146 - 161; ISBN 978-93-82135-95-1.

17. DFID Malawi. (2004), "Terms of reference for a gender consultant to undertake a gender audit of the DFID Malawi Programme", DFID Malawi.

18. Diamond, N.K, L. Squillante, and L.Z. Hale. (2003), "Crosscurrents: navigating gender and population linkages for integrated coastal management". Marine Policy, Vol. 27, No.4, pp. 325331.

19. DRWA. (2013), Directorate of Research on Women in Agriculture, Technical Bulletin-25, 2013, ICAR.

20. Durai, J.A, and J. Dhanalakshmi. (2015), "Role of women in the fishery sector in Tamilnadu". International Journal of Application or Innovation in Engineering \& Management, Vol.10, No.4, pp.9-13.

21. ECOSOC. (1997), "Agreed Conclusions 1997/2, 18 July 1997". UN Economic and Social Council, pp. 12. 
22. Edilberto Loaiza and Mengjia Liang. (2013), "Adolescent Pregnancy: A Review of the Evidence". New York, UNFPA, pp. 1-53.

23. Elizabeth Ursic. (2014), "Women, Ritual, and Power: Placing Female Imagery of God in

24. Christian Worship". SUNY Pres, pp.1-235. ISBN 1438452861, 9781438452869.

25. Elson, Diane. (1997), "Gender-Neutral, Gender-Blind, or Gender-Sensitive Budgets? Changing the Conceptual Framework to Include Women's Empowerment and the Economy of Care," Preparatory Country Mission to Integrate Gender into National Budgetary Policies and Procedures, London: Commonwealth Secretariat.

26. Esther Duflo. (2012), "Women Empowerment and Economic Development." Journal of Economic Literature, Vol. 50 No.4, pp. 1051-1079.

27. Ethel Mary Brinda, Anto P Rajkumar, and Ulrika Enemark. (2015), "Association between gender inequality index and child mortality rates": a cross-national study of 138 countries. BMC Public Health, No 15, 97, pp. 1-6.

28. Fagan, C., J. Rubery, D. Grimshaw, M. Smith, G. Hebson and H. Figueiredo.( 2005), "Gender Mainstreaming in the Enlarged European Union": Recent Developments in the European Employment Strategy and Social Inclusion Process', Industrial Relations Journal, Vol,36, No.6, pp. 568-591.

29. FAO. (1990). "Women, Agriculture and Rural Development": Gender issues in Rural Food Security in Developing Countries. Rome, Italy.

30. FAO. (2013), "Good practice policies to eliminate gender inequalities in fish value chains". 1-120, FAO - E-ISBN 978-92-5-108102-0.

31. FAO. (2014), "The State of World Fisheries and Aquaculture Opportunities and challenges".

32. FAO. (2016) "Promoting gender equality and women's empowerment in fisheries and aquaculture." Social Policies and Rural Institutions Division, Economic and Social Development Department, Fisheries and Aquaculture Department, Food and

33. Agriculture Organization of the United Nations, FAO I6623EN/1/12.16, pp. 1-12.

34. Fedon, P. (2004), "Gender inequality hampers Philippine economic development". Finance Wire. http://search.proquest.com.dbgw.lis.curtin.edu.au/docview/467111986/fulltext/13D529CDA0575 6DBEB1/4? accounted $=10382$.

35. Frank Chirowa, Stephen Atwood, and Marc Van der Putten. (2013), "Gender inequality, health expenditure and maternal mortality in sub-Saharan Africa": A secondary data analysis. African Journal of Primary Health Care \& Family Medicine, 1, No. 5, pp. 471.

36. Gai elle Ferrant. (2010). "The Gender Inequalities Index (GII) as a new way to measure Gender Inequalities in Developing countries". HAL publication, ISSN: 1955-611X HALL Id: hash-00462463.

37. Ghosh, Archana \& Lama-Rewal, Stéphanie Tawa. (2005), "Democratization in Progress": Women and Local Politics in Urban India. New Delhi: Tulika Books. 
38. GOI. (2013), "Provisional Estimates of Annual National Income, 2012-13", Ministry of Statistics and Programme Implementation, Government of India, New Delhi

39. Hallman, K. (2000), "Mother-father resource control, marriage payments, and girl-boy health in rural Bangladesh". International Food Policy Research Institute, Washington DC.

40. Harrison, E. (2001), "Gender; rights and poverty issues: lessons for the sector". Backg round paper for DFID/FGRP- 3/ARP Workshop on practical strategies for poverty targeted research; 7-11 November. Overseas Development Institute, pp.23.

41. HDR. (2014), "Sustaining human progress, reducing vulnerabilities and building resilience.

42. ICOR. (2011). "Nutritional and Health Status of Fishing Communities in the Uttan-Gorai area with Special Emphasis on Women". Published by Institute for Community Organisation Research. Mumbai, Sponsored by Narotam Sekhsaria Foundation, pp. 1- 53.

43. ILO. (2002), "Definition of Gender Mainstreaming". 〈http://www.ilo.org/public/english/bureau/gender/newsite2002/about/defin.htm〉.

44. Jahn, A, and V, De Brouwere. (2001) "Referral in pregnancy and childbirth: Concepts and strategies." Studies in Health Services Organisation and Policy, 17, pp. 229-246.

45. Janet G. Stotsky, Sakina Shibuya, Lisa Kolovich, and Suhaib Kebhaj. (2016), "Trends in Gender Equality and Women's Advancement. IMF Working paper. WP/16/21, pp. 1- 62.

46. Johnson, D., 1985. "The development of social statistics and indicators on the status of women". Social Indicators Research, 16, pp. 233-261.

47. Karuna Anbarasan. (1985), "Factors that influence the role and status of fisherwomen". Bay of Bengal Programme, Development of small scale fisheries. BOB P/WP/33, pp. 1- 16.

48. Khader, V., Kumar, R.N., Lakshmi, J., Dhanapal, Kasim, H.M., Sathiadhas, R., Sudhakara, N.S. (2004), "Nutritional status and socioeconomic empowerment of fisherwomen in the coastal ecosystem of Andhra and Tamilnadu, India". Global symposium on gender and Fisheries 7th Asian Fisheries forum 1-2 December, Penang, Malasia.

49. Kolandaswamy, K. (2010), "Maternal mortality in Tamil Nadu during 2001-10": Varied progress in reducing maternal mortality at the health district level and preventable causes remain unchanged, Unpublished dissertation, National Institute of Epidemiology, Chennai.

50. Maetala, R. (2009). "Gender issues in fisheries". A look into gender issues in Solomon Islands Fisheries. Report Prepared for the NZAID Fisheries Review.

51. Maruf Hossan Chowdhury, Mohammed Naim A. Dewan, Mohammed Quaddus, Marita Naude, and Abu Siddique. (2015), "Gender equality and sustainable development with a focus on the coastal fishing community of Bangladesh". Discussion paper 14.10 of Graduate School of Business Curtin University, Perth, Australia.

52. Matthews, Elizabeth, Jamie Bechtel, Easkey Britton, Karl Morrison, and Caleb McClennen. (2012), "A Gender Perspective on Securing Livelihoods and Nutrition in Fish - dependent Coastal Communities". Report to the Rockefeller Foundation from Wildlife Conservation Society, Bronx, NY. 
53. Menu Maheshwari, Shobhna Goyal., 2014. "Role of Self Help Groups in Socio-Economic Empowerment of women": A review of Studies. Pacific Business Review International, Vol. 2, No.7, pp. 85-93.

54. Montgomery AL, U Ram, R Kumar, and P Jha.,2014. "Maternal mortality in India": Causes and healthcare service use based on a nationally representative survey, 9(1): e83331.

55. Muni, S.D. (1979), "Women in the Electoral Process". A Statistical Analysis of the Lok Sabha Elections'. In Vina Mazumdar (Ed.) Symbols of Power: Studies on the Political Status of Women in India, Bombay: Allied Publishers, pp. 24-50.

56. Muraleedharan, V, U Dash, and L Gilson. (2011), "Tamil Nadu 1980s-2005": A success story in India, in D Balabanova, M Mckee and A Mills (eds), London School of Hygiene and Tropical Medicine, London.

57. Nag, P.K., and A Nag (2007), "Hazards and health complaints associated with fish processing activities in India": Evaluation of a low-cost intervention. International Journal of Industrial Ergonomics No.3, pp. 125-132.

58. Natarajan, B, and B. Vijay. (2014). "Coastal Women Empowerment in Tamil Nadu with special reference to India". Vol. 4, No.4, pp. $170-178$.

59. Nguyen Dang Hao. (2012), "Gender Issues in the Fishery Communities of the Central Coastal Provinces of Vietnam". Asian Fisheries Science Special Issue, No. 25, pp. 129-143.

60. Nikita Gopal, Leela Edwin, and B. Meenakumari. (2014), "Transformation in Gender Roles with Changes in Traditional Fisheries in Kerala, India". Asian Fisheries Science Special Issue, 27 S pp. 67-78.

61. Patalk, S; Baral, J.K; Dash, M.K. (2011), "Socio-cultural life of fisherwomen in India - continuity, and change-with special reference to Orissa state". International Journal of Sociology and Anthropology, Vol. 3, No.10: 340-353.

62. Paul Jose P.C. (2016), "Empowerment of fisherwomen in fish processing and vending sectors - an Analysis. EPRA International Journal of economic and Business review, Vol. 4, No.7, pp. 26-28.

63. Pereira. (2004), "Women in Fisheries in Latin America." Global symposium on gender and Fisheries 7th Asian Fisheries forum 1-2 December, Penang, Malasia.

64. Planning Commission. (2010), "Engendering Public Policy," A Report on the work of the Working Group of Feminist Economists during the Preparation of Eleventh Five Year Plan, 2007-2012, pp. $1-61$.

65. Praveen Rai. (2017), "Women's participation in electoral politics in India: silent feminisation". South Asia Research, Vol. 37, No.1, pp. 58-77.

66. Quisumbing, A. R. (2003) "Household decisions, gender, and development: A synthesis of recent research." International Food Policy Research Institute, Washington, D.C.

67. RGI. (2013), "Special bulletin on maternal mortality in India". New Delhi: Office of the Registrar General \& Census Commissioner, India, New Delhi.

68. Riquer, F. (1993), "Población y género. Consejo Nacional de Población" (CONAPO). México. 
69. Rubery, Damian Grimshaw, and Hugo Figueiredo. (2005), "How to close the gender pay gap in Europe: towards the gender mainstreaming of pay policy", Industrial relations Journal Vol.36, No.3, pp. 184-213.

70. Rupnawar, B.S, and Upadhye, S.G. (2015), "Women empowerment through self-help group: A study of Karjat Taluka Raigad district Maharashtra. International Journal of Multidisciplinary Research and Development, Vol.2 No.10, pp 568-571.

71. Sheela Immanuel, Narayana Kumar. R., Ayyappan, S. (2008), "Sustainable Alternate Livelihood Avocations for Coastal Women in India." J. of Agricultural Situation in India, Vol.65, No.2, pp. 8388.

72. Siason, I.M., E Tech, K.I. Matics, P Choo, M Shariff, E.S. Heruwati, T Susilowati. (2010), "Women in Fisheries in Asia. www.worldfishcenter.org/Pub., s/Wif/wifglobal/wifg_asia.pdf>

73. Srinath, K. (1987), "Some observations on the food consumption pattern and nutritional status of the fishermen community". Mar. Fish. Infor. Serv, 89. C. M.F.R.I. Cochin.

74. Subha Sri B and R Khanna. (2014), "Dead women talking: A civil society report on maternal deaths in India", Common Health, Jan Swasthya Abhiyan, July.

75. Sundaravaradarajan. (2004), "Final Technical Report Globalization and its Impact on the displacement of fisherwomen in major fishing harbors of Andhra Pradesh and Tamil Nadu, Department of Women and Child Development, Ministry of Human Resource Development, Government of India, New Delhi.

76. The Global Gender Gap Report. (2013), World Economic Forum. "This week ranks India at 101 among 136 countries that were assessed for women empowerment on social, economic and political parameters".

77. Thomas, Sue and Wilcox, Clyde. (2005), "Women and Elective Office: Past, Present, and Future." New York, Oxford University Press.

78. Tietze, Uwe, and FAO. (2007). "Livelihood and micro-enterprise development opportunities for women in coastal fishing communities in India": case studies of Orissa and Maharashtra. Food and Agriculture Organization of the United Nations, Rome.

79. Torell, E., Owusu, A., and Okyere Nyako, A. (2016), "Gender mainstreaming in fisheries Management": A training manual. The USAID/Ghana Sustainable Fisheries Management Project (SFMP). Narragansett, RI: Coastal Resources Center, Graduate School of Oceanography, and the University of Rhode Island.GH2014_GEN003_SNV: 20.

80. Tripathi, Tiwari, and Kamath. (2016), "Workplace Violence and Gender Bias in Unorganized Fisheries of Udupi, India". International Journal of Occupational and Environmental Medicine, 7 No.3, pp. 181-185.

81. UNDP. (2014), "Human Development Report", New York, UNDP.

82. UNEP. (2010), "Gender mainstreaming: 10 steps for integrating gender into the policy-making process" Part I, United Nations Environment Programme, Nairobi. 
83. UNFPA. (2010), "Sexual and Reproductive Health for All Reducing poverty, advancing development and protecting human rights, pp. 1-80. The publication was available at http://www.unfpa.org/public/ho me/publications/pid/6526.

84. Van Ingen, C. Kawau, and S. Wells. (2002), "Gender Equity in Coastal Zone Management: Experiences from Tanga, Tanzania". Publication of Tanga Coastal Zone Conservation and Development Programme. IUCN Eastern Africa Regional Programme, pp. 1- 39.

85. Weeratunge, N., Snyder, K.A. and Choo, P.S. (2010), "Gleaner, fisher, trader, processor: understanding gendered employment in fisheries and aquaculture". Fish and Fisheries, 11, pp. 405-420.

86. WHO. (2011), "Preventing early pregnancy and poor reproductive outcomes among adolescents in developing countries" WHO guidelines: 195 - who publication. SBN: 9789241502214 Available - at http://www.who.int/reproductivehealth/publica tions/adolescence/9789241502214/e n/ visited 8/8/2011.

87. WHO. (2012), "Early marriages, adolescent and young pregnancies". SIXTY- FIFTH WORLD HEALTH ASSEMBLIES. A65/13, pp. 1-4.

88. William Joe, Suresh Sharma, Jyotsna Sharma, Y Manasa Shanta, Mala Ramanathan, Udaya Shankar Mishra, and B Subha Sri. (2015), "Maternal Mortality in India: A Review of Trends and Patterns". IEG Working Paper No. 353. Institute of Economic Growth, Delhi, pp. 1-32.

89. Williams, M, S Williams, and P Choo. (2002), "From Women in Fisheries to Gender and Fisheries", Global Symposium on Women in Fisheries: Sixth Asian Fisheries Forum, Kaohsiung, Taiwan.

90. World Bank. (2010), "India marine Fisheries- Issues, Opportunities, and Transitions for Sustainable Development.

91. World Bank (2012), "Gender Equality and Development," World Development Report, World Bank, Washington. 